\title{
Oordeelsvorming bij cijferanalyse
}

\section{Conclusies uit cognitief onderzoek}

Drs. P.W.A. Eimers, Prof. Dr. S.F. Biggs en Prof. Dr. T.J. Mock

\section{Inleiding'}

Reeds geruime tijd doen accountants(kantoren) onderzoek om hun controlemethoden effectiever en efficiënter te maken (zie bijvoorbeeld Kreutzfeldt en Wallace (1986), Houghton en Fogarthy (1991) en Wallage (1993). Als gevolg van een toegenomen concurrentie tussen accountantskantoren en dalende controlebudgetten, is het bovendien voor accountantskantoren van belang om met de aanwezige controlemiddelen efficiency-verhoging van controlewerkzaamheden te realiseren, zonder afbreuk te doen aan de effectiviteit van de controle. Cijteranalyse is een controlemiddel walarmee deze efficiency- en effectiviteitsverbetering kan worden bereikt, ondat cijferanalyse ten opzichte van andere controlemiddelen eenvoudig is te hanteren en tevens belangrijk blijkı te zijn voor het signaleren en ontdekken van materiële fouten in de jaarrekening. Wright en Ashton (1989) stelden op basis van controledossiers vast dat de helft van alle door de accountant ontdekte fouten in de jaarrekening werd ontdekt door de drie signalerende controleprocedures in de eenvoudigste vorm: cijferanalyse door vergelijking van de cijfers van vorig jaar met dit jaar, inlichtingen van de cliënt en verwachtingen op basis van de voorafgalande controle. Alleen al door cijferanalyse werd $16 \%$ van de materiële fouten ontdekt. De respondenten in de Wright en Ashton studie gaven daarbij te kennen dat een aanzienlijk deel van de materiële fouten niet zou zijn gesignaleerd door andere controlemiddelen en een groot deel van de met andere controlemiddelen ontdekte fouten ook met cijferanalyse had kunnen worden ontdekt.

Sinds de jaren zeventig richt onderzoek op het gebied van cijferanalyse zich op de mogelijke verhoging van de efficiency en effectiviteit van de controle. In de jaren zeventig was het onderzoek geconcentreerd op het ontwikkelen van statistische modellen. In de jaren tachtig en negentig echter heeft het zwalartepunt van onderzoek naar cijferanalyse zich verplaatst van een statistische naar een cognitieve benadering. Deze cognitieve benadering onderscheidt zich van de statistische benadering, doordal de cognitieve benadering gericht is op het onderkennen van beslissingsprocessen van de accountant en niet op economische relaties tussen onderzoeksobjecten.

Er bleek namelijk dat statistische modellen weliswaar de potentie hebben om efficiency- en effectiviteitsverhogend te werken, maar dat de verschillende omgevingsvariabelen in de praktijk de waarde van statistische modellen beperken. Onderzoekers hebben zich daarom gericht op de totstandkoming van oordeelsvorming van de accountant bij het uitvoeren van cijferanalyses. Startend met de cognitieve beschrijving van de oordeelsvorming, hebben onderzoekers vervolgens een reeks van beïnvloedende factoren van oordeelsvorming uitgetest in verschillende onderzoeksvormen (verbale protocol analyse, case-studies, interviews, experimenten, archiefstudies). Deze

Drs. P.W.A. Eimers is werkzaam bij Coopers \& Lybrand N.V. te Arnhem en verricht een promotie-onderzoek bij het Maastricht Accounting \& Auditing Research Center (MARC) Dit artikel is geschreven op persoonlijke titel.

Prof. Dr. S.F Biggs is KPMG Peat Marwick Professor of Accounting aan de University of Connecticut, USA.

Prof. Dr. T.J. Mock is Arthur Andersen Alumni Professor of Accounting aan de University of Southern California te Los Angeles, USA en Professor of Audit Research bij het Maastricht Accounting \& Auditing Research Center (MARC). 
onderzoeken hebben geleid tot een aantal bevindingen die van belang zijn voor de uitvoering van cijferanalyse in de praktijk.

Het doel van dit artikel is accountants uit de praktijk een overzicht te geven van de cognitieve benadering van cijferanalyse en de bijdrage van cognitief onderzoek naar cijferanalyse aan de praktijk. In paragraaf 2 wordt allereerst in hoofdlijnen de cognitieve benadering beschreven aan de hand van het cognitieve model van Biggs, Mock en Watkins. Paragraaf 3 bevat de voornaamste onderzoeksbevindingen en de implicaties voor de praktijk. Het artikel wordt in paragraaf 4 afgesloten met een samenvatting.

\section{Het beslissingsproces van de accountant bij de uitvoering van cijferanalyse}

Cijferanalyse is "gericht op het onderkennen en analyseren van betekenisvolle verhoudingscijfers en trends inclusief het daaruit voortvloeiende onderzoek naar de oorzaak van de fluctuaties en de verbanden die strijdig zijn met andere relevante gegevens of die afwijken van de verwachte bedragen" (NIVRA, 1996, p. 337). Cijferanalyse is een verzamelbegrip van de controlemiddelen "cijferbeoordeling', 'totaal-en verbandscontrole' en 'controle met budgetten en normen' (Ten Wolde, 1989, 1990). Alhoewel verbandscontrole in de Nederlandse traditie een bekend begrip is, is dat niet expliciet het geval in de Angelsaksische traditie. Blokdijk bekritiseert om deze reden de verzamelnaam 'cijferanalyse' voor cijferbeoordeling en verbandscontrole (Blokdijk, 1996, p. 356). Het belangrijkste verschil tussen verbandscontrole en cijferbeoordeling is namelijk dat verbandscontrole uitgaat van een bekende relatie (verificatie) en cijferbeoordeling van een verwachte relatie (vergelijking) tussen cijferopstellingen (zie Blokdijk, Drieënhuizen en Wallage, 1995, p. 48, waar het begrip verbandscontrole voor de Angelsaksische lezers wordt uitgelegd als 'coherence testing').

Het verrichten van cijferanalyse door de accountant is een complexe taak die de nodige kennis en vaardigheden vereist. Onderzoekers hebben onderkend dat de aard van cijferanalyse niet zozeer het procedureel doorlopen van vooraf bepaalde stappen is, maar dat er veel probleemgericht en stapsgewijs redeneren bij komt kijken. De in de Angelsaksische literatuur gehanteerde omschrijvingen 'Analytical Procedures' en 'Analytical Review' geven dit verschil duidelijk aan. De eerste omschrijving refereert aan de specifieke stappen die een accountant volgt als hij de cijferanalyse uitvoert. De tweede omschrijving is toepasselijker, omdat deze refereert aan het diagnostisch proces van identificeren, onderzoeken en oplossen van onverwachte fluctuaties (zie Koonce, 1993). Onderzoekers hanteren daarom dikwijls de term 'Analytical Review Procedures' om van deze discussie verlost te zijn.

Het diagnostisch proces is qua aard niet specifiek voor cijferanalyse of voor de accountant in het algemeen, maar is net zo van toepassing voor professionals in andere beroepsgroepen. Zo is het diagnostisch proces van de accountant bijvoorbeeld vergelijkbaar met de diagnose die een arts stelt bij het onderzoeken van een patiënt. De arts verricht een aantal onderzoeken en vergelijkt de resultaten ervan met de verwachtingen die hij heeft van een gezond persoon. Hieruit komt een ziektebeeld naar voren en kan vervolgens een behandeling worden aanbevolen. Vertaald naar cijferanalyse confronteert de accountant de op dat moment nog ongecontroleerde cijfers met de verwachtingen die hij vooraf al dan niet specifiek heeft geformuleerd. Hij zoekt naar de oorzaken van onverwachte fluctuaties om potentiële fouten in de verantwoording te signaleren. Afhankelijk van de aard en omvang van de onverwachte fluctuatie neemt de accountant een beslissing over de aard, omvang en timing van de nader uit te voeren werkzaamheden.

Biggs, Mock en Watkins (1988, 1989) hebben een procesmodel ontwikkeld dat het beslissingsproces van de accountant beschrijft bij het uitvoeren van cijferanalyses. Dit model sluit aan bij eerder onderzoek in de cognitieve psychologie. Alhoewel het model met name het proces beschrijft van de initiële cijferanalyse, is het model ook bruikbaar voor de cijferanalyse tijdens de uitvoerings- en evaluatiefase.

Het beslissingsproces van de accountant (zie figuur 1) begint met het stellen van een doel dat met de cijferanalyse moet worden bereikt ('set goal') (stap 1). Dit doel is in het algemeen het signaleren van onverwachte fluctuaties in de verantwoording. die aanleiding kunnen geven voor nader onderzoek. Een daaraan gerelateerde doelstelling is het identificeren van posten die 


\section{FASE IN HET BESLISSINGSPROCES}

Formuleer de doelstelling van de cijferanalyse

Breng globaal het probleem in kaart

3

Ontwikkel verwachtingen

4

Vergelijk de gerapporteerde cijfers met de verwachtingen

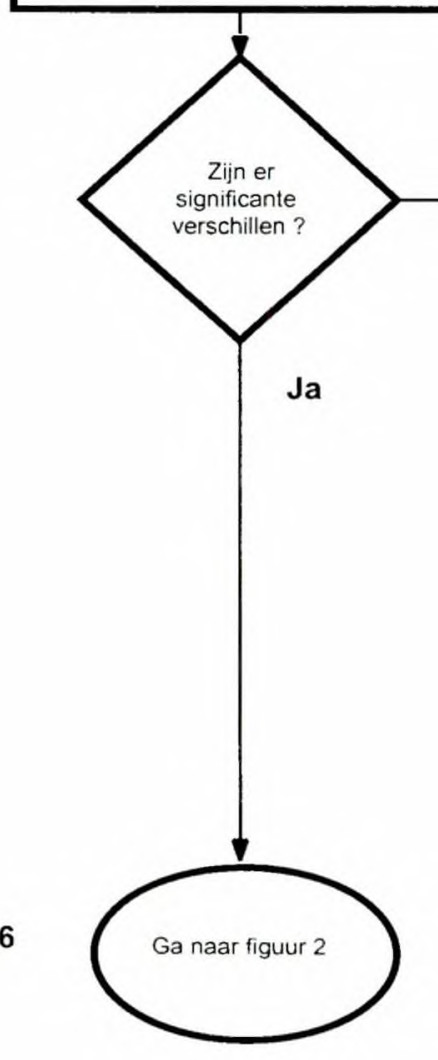

\section{VOORNAAMSTE ACTIVITEIT}

Signaleren van onverwachte fluctuaties die verder onderzoek behoeven en het

identificeren van gebieden waar mogelijk de overige controlewerkzaamheden kunnen worden verminderd.

Nagaan wat de kritische elementen zijn in de cijfers, ratio's en trends (wat zijn de kenmerken van het bedrijfsproces van de klant, welke ratio's zijn bepalend etc.

Formuleren van verwachtingen voor de cijfers, gebruikmakend van de kennis van de cliënt.

branche, economie etc

Vergelijken en evalueren van verschillen tussen verwachtingen en de nog te controleren cijfers

Bron: Biggs, Mock en Watkins (1995) 
minder intensief hoeven te worden beoordeeld als de cijferanalyse geen onverwachte fluctuaties aangeeft. Om het doel te bereiken maakt de accountant gebruik van een zogenaamd 'informatie-zoek-proces'. Dit zoekproces bestaat uit twee belangrijke delen: Probleemvoorstelling ('generate problem representation') (stap 2) en het ontwikkelen van een aantal verwachtingen ('develop expectations') (stap 3).

De probleemvoorstelling - bijvoorbeeld het nagaan wat de kritische elementen zijn in de cijfers, ratio's en trends - is een cognitief proces dat is gebaseerd op de kennis die de accountant heeft voor de uitvoering van cijferanalyse. Deze kennis bestaat niet alleen uit vaktechnische kennis over boekhouden en controletechnieken, malar ook uit de kennis hoe mogelijke fouten de te controleren cijfers kunnen beïnvloeden, en voorts uit specifieke kennis over de cliënt en de branche. Deze globale probleemvoorstelling is een belangrijke stap. omdat zij een uitgangspunt biedt voor het verdere verloop van de uitvoering van de cijferanalyse.

De probleemvoorstelling is de basis voor hel ontwikkelen van een aantal verwachtingen (stap 3). In deze fase specificeert de accountant zijn algemene probleemvoorstelling uit stap 2 tot specifieke verwachtingen. Als een cliënt bijvoorbeeld te maken heeft met toenemende concurrentie (de probleemvoorstelling in stap 2), dan zal de accountant verwachten dat de brutomarge ten opzichte van vorig jaar onder druk komt te staan (de verwachting in stap 3). De nog te controleren cijfers worden vergeleken met de verwachtingen hieromtrent ('compare reported with expectations to identify significant discrepancies') (stap 4). Hierbij zal de beslissing voor nader onderzoek mede worden bepaald door de alard en grootte van de onverwachte fluctuatie, gerelateerd aan het controlerisico en de gestelde materialiteit.

Als er in het kader van het controlerisico en de gestelde materialiteitsgrenzen geen sprake is van een onverwachte fluctuatie tussen de verwachte en de actuele cijfers, heeft de accountant de keuze uit drie mogelijkheden (stap 5). Deze keuze wordt bepaald door de mate van vertrouwen die de accountant heeft in de bewijskracht van cijferanalyse. Dit vertrouwen is afhankelijk van de in de planningsfase beoordeelde achtergrondinformatie inzake externe en interne factoren, de gestelde materialiteitsgrens en het maximaal aanvaardbare controle- en inherent risico, het doorgronden van het stelsel van interne controle en de vaststelling van het interne controlerisico.

In de eerste plaats moet de accountant zich afvragen of de cijferanalyse zoveel bewijskracht heeft dat hierdoor geen nadere controlemaatregelen nodig zijn ("accept assertion of financial balance'). In dit geval gebruikt de accountant cijferanalyse ook als een gegevensgerichte controleprocedure. In de tweede plaats kan de accountant overwegen dat de cijferanalyse voldoende aanleiding geeft tot het verminderen van overige controlemaatregelen, maar dat aanvullende zekerheid nodig is ('reduce specific detailed tests'). Tot slot kan de accountant beslissen om de geplande controlewerkzaamheden niet aan te passen na het uitvoeren van cijferanalyse ('conduct planned detailed tests') en dus de oorspronkelijke planning van werkzaamheden aan te houden.

Als de accountant echter wordt geconfronteerd met een in het kader van gestelde materialiteitsgrenzen significant verschil tussen zijn verwachtingen en de actuele cijfers ('significant discrepancies identified') (figuur 2,stap 6), kan dit een indicatie zijn dat (een deel van) de verantwoording mogelijk onjuist is. Het achterhalen van de oorzaak van de onverwachte fluctuaties is derhalve belangrijk voor het ontwikkelen van de aard en omvang van de uit te voeren controlestappen. Vanaf het moment dat de accountant van mening is dat de fluctuatie significant is, zal hij moeten trachten deze fluctuatie te verklaren. De fluctuatie kan zijn ontstaan door twee oorzaken. In de eerste plaats kan het een onjuistheid zijn (een 'error'oorzaak), zoals een verkeerde wijze van boeken of het ontbreken van afsluitende werkzaamheden in de administratie. In de tweede plaats kan het een fluctuatie zijn die door iets anders wordt veroorzaakt dan door een foutieve wijze van boeken (de 'non-error' oorzaken), zoals toevallige fluctuaties, conjuncturele en brancheontwikkelingen of bijzondere transacties.

Het achterhalen van de oorzaak van de onverwachte fluctuatie omvat twee stappen: Ten eerste het nadenken of ervaringen met in het verleden gesignaleerde probleemsituaties kunnen helpen naar het zoeken van de mogelijke oorzaak van de huidige fluctuatie ('generate enhanced problem representation') ( $(\operatorname{stap} 7)$ en ten tweede het brainstormen over de mogelijke oorzaken van de fluctuatie ('generate hypotheses') (stap 8). Door- 


\section{FASE IN HET BESLISSINGSPROCES}

(Vervolg van figuur 1)

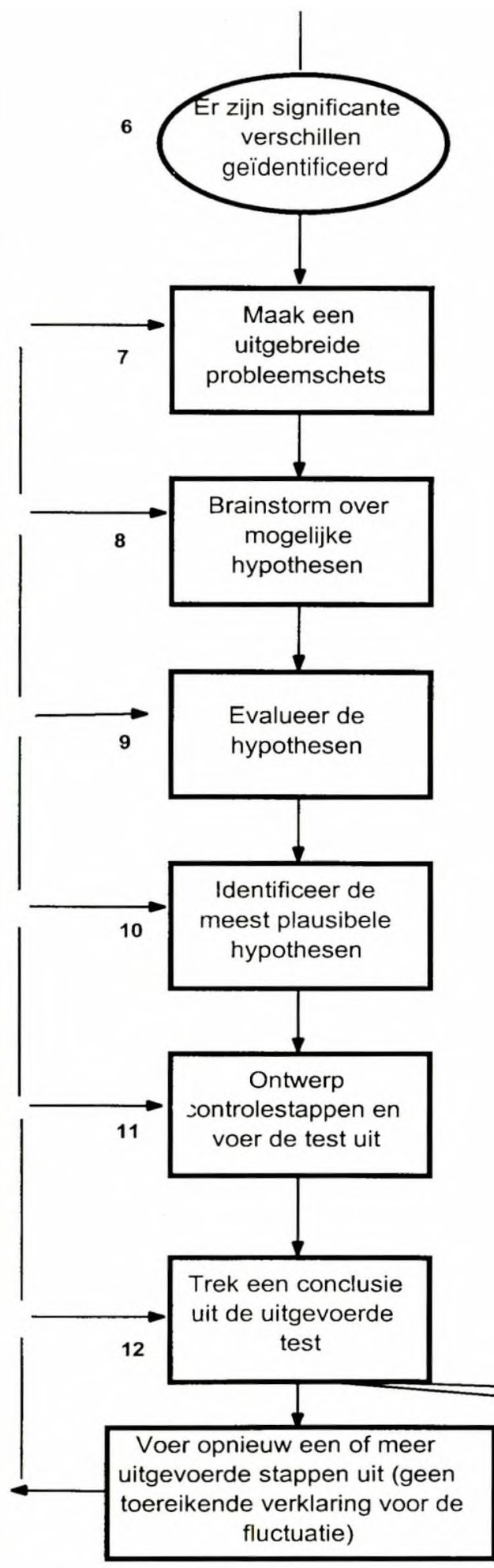

12.1
Nagaan of op basis van ervaring in het verleden er specifieke situaties zijn, die relevant zijn voor het begrijpen van oorzaken voor de significante verschillen.

Identificeren van een of meer mogelijke oorzaken van de onverwachte fluctuatie.

Per geformuleerde hypothese vaststellen of de veronderstelde oorzaak de onverwachte fluctuatie kan verklaren.

Selecteren van hypothesen die het meest voor de hand liggen om verder te onderzoeken.

Opstellen en uitvoeren van controlestappen die specifiek gericht zijn op het verkrijgen van zekerheid over de juistheid van de geselecteerde hypotheses.

Evalueren in hoeverre de resultaten van de uitgevoerde testen de onverwachte fluctuatie verklaren.

\footnotetext{
Bron: Biggs, Mock en Watkins (1995)
}

Vraag de cliënt de verantwoording aan te passen (error-oorzaak)
Onderneem geen verdere actie (non-error-oorzaak) 
dat de accountant nu de actuele cijfers heeft vergeleken met zijn verwachtingen, kan hij specifiek op zoek gaan naar mogelijke oorzaken. Het putten uit het geheugen voor vergelijkbare probleemsituaties is een specifieke invulling van stap 2, waar slechts een globale weergave van de probleemvoorstelling plaatsvond. Hoewel het mogelijk is om naar één enkele onverwachte fluctuatie te kijken, is het raadzaam om ook te zoeken naar verbanden tussen posten in de jaarrekening ('pattern recognition'). Deze aandacht voor verbanden tussen fluctuaties wordt ingegeven door het systeem van dubbel boekhouden, waarbij één boeking gevolgen heeft voor ten minste twee grootboekrekeningen. Als bijvoorbeeld een grote verkoopaflevering vlak voor balansdatum dubbel is geboekt, heeft dit ten minste gevolgen voor zowel de omzet in de laatste maand als de post debiteuren per jaareinde. De brainstormfase van het ontwikkelen van hypothesen ( $\operatorname{stap} 8$ ) is zeer belangrijk, omdat verdere controlewerkzaamheden specifiek op deze oorzaken kunnen worden gericht. Hierdoor is het mogelijk om de efficiency van de uitvoering van cijferanalyse te verbeteren.

Als de mogelijke hypothesen zijn geformuleerd, evalueert de accountant of elke hypothese de onderliggende onverwachte fluctuatie (of verbanden tussen fluctuaties) voldoende kan verklaren ('evaluate hypotheses') (stap 9). In het genoemde voorbeeld van de dubbele omzetboeking in de laatste maand, zal de accountant moeten nagaan of de hogere verantwoorde omzet die wordt veroorzaakt door de dubbel geboekte verkooporder, een afdoende verklaring biedt voor de feitelijk gesignaleerde omzetstijging in de laatste maand en het gestegen saldo van de debiteuren. De hypothesen die de onverwachte fluctuatie niet (voldoende) verklaren, worden geschrapt. Deze evaluatie van hypothesen is, rekening houdend met de benodigde tijdsbesteding, relatief goedkoop in verhouding tot het uitvoeren van controlestappen die elke hypothese zou moeten bevestigen of wel ontkrachten. Door deze vroegtijdige evaluatie wordt de mogelijke efficiency van cijferanalyse benut.

Nadat de accountant de hypothesen heeft geëvalueerd, kan hij de overblijvende meest plausibele hypothesen beoordelen aan de hand van zijn kennis van de cliënt ('identify most plausible hypotheses') (stap 10). Voor deze hypothesen stelt hij een plan op voor aanvullende werkzaamheden die moeten aantonen of de onverwachte fluctuatie wordt veroorzaakt door een onjuistheid, of aanvullende zekerheid moeten opleveren dat er sprake is van een 'non-error'-oorzaak ('design \& perform audit test of hypotheses') (stap 11). Als deze hypothesen zijn getest, kan de accountant de resultaten evalueren ("draw audit conclusion') (stap 12) en beslissen of aanvullende controles moeten worden uitgevoerd ( 'reperform one or more prior steps') (stap 12.1), of dat de onjuistheid is geïdentificeerd en moet worden gecorrigeerd ('require client to adjust books') (stap 12.2) of dat de non-error-hypothese voldoende is aangetoond ('conclude that non-error explanation is valid') (stap 12.3).

\section{Bevindingen van cognitief onderzoek en implicaties voor de praktijk}

Cognitief onderzoek naar de oordeelsvorming van de accountant bij de uitvoering van cijferanalyse heeft nuttige bevindingen opgeleverd met implicaties voor de praktijk. De voornaamste bevindingen en mogelijke implicaties zijn opgenomen in tabel 1. Gezien de aard van dit artikel beperken wij ons tot literatuurverwijzingen.

Een van de bevindingen is dat ervaren accountants beter in staat zijn om onverwachte fluctuaties te signaleren dan minder ervaren collega's. Zij kunnen dan ook beter verbanden tussen fluctuaties van posten in de jaarrekening herkennen. Deze ervaring hoeft niet alleen betrekking te hebben op algemene praktijkervaring, maar ook op brancheervaring of ervaring bij de betreffende cliënt. Kennisoverdracht van de ervaren accountants naar de beginnende assistenten is belangrijk voor een efficiënte en effectieve uitvoering van de controle. Dit is vooral van belang omdat veel accountantskantoren jaarlijks een aanzienlijke instroom hebben aan onervaren assistenten en de samenstelling van controleteams jaarlijks kan wijzigen. Specifieke aandacht voor het onderkennen van oorzaken en verbanden tussen posten in de jaarrekening tijdens reviews, in controlehandleidingen en tijdens interne en externe cursussen, kan hierbij een goede methode voor kennisoverdracht zijn.

Verder blijkt dat accountants moeite hebben om meer dan één plausibele hypothese te genereren, omdat zij de tweede hypothese onbewust associëren met de eerste hypothese. De denkrichting voor een tweede hypothese is hierdoor 
beperkt. In de praktijk doet zich dit probleem voor als de cliënt een verklaring geeft voor een door de accountant geconstateerde onverwachte fluctuatie van één of meer posten in de jaarrekening. Het kennisnemen van deze verklaring beperkt de accountant in het nadenken over mogelijke andere oorzaken.

Bovendien blijkt dat de accountant minder onverwachte fluctuaties herkent tijdens de uitvoe- ring van de cijferanalyse, als hij de cijferanalyse start met het kennisnemen van de nog te controleren cijfers. Dit houdt in dat het risico op het niet signaleren van onverwachte fluctuaties toeneemt. Het gevolg kan tweeledig zijn. In de eerste plaats kan de efficiency van de controle afnemen (het in een latere fase van de controle constateren van een fout kost meer tijd dan het eerder signaleren met cijferanalyse). In de tweede plaats kan de effecti-

\section{Tabel 1: Belangrijkste onderzoeksbevindingen en implicaties voor de praktijk}

Bevinding 1 en 2 zijn apart in de tabel opgenomen in verband met de verwijzing naar specifieke literatuur.

\begin{tabular}{|c|c|c|}
\hline Onderzoeksbevindingen & Implicaties voor de praktijk & Literatuurverwijzing \\
\hline $\begin{array}{l}1 \text { Accountants die een hypothese genereren } \\
\text { voor een onverwachte fluctuatie, hebben } \\
\text { moeite om additionele plausibele hypothesen } \\
\text { te genereren als gevolg van een onbewuste } \\
\text { associatie met de ecrste hypothese. }\end{array}$ & $\begin{array}{l}\text { Accountants zouden moeten overwegen om } \\
\text { hun eigen verwachtingspatroon op te bouwen. } \\
\text { voordat ze om een verklaring vragen uit een } \\
\text { andere bron, met name vanuit de cliënt. }\end{array}$ & $\begin{array}{l}\text { Libby, } 1985 \\
\text { Libby en Frederick. } 1990 \\
\text { Heiman. } 1990 \\
\text { Bedard en Biggs, 1991b } \\
\text { Anderson. Kaplan en Reckers, } 1992 \\
\text { Bedard. Biggs en DiPietro, } 1993 \\
\text { Koonce, } 1992\end{array}$ \\
\hline $\begin{array}{l}2 \text { De accountant is minder goed in staat om } \\
\text { onverwachte fluctuaties te signaleren als hij } \\
\text { de cijferanalyse start met het kennisnemen } \\
\text { van de nog te controleren cijfers. Dit effect } \\
\text { wordt versterkt als de verklaringen voor de } \\
\text { fluctuaties van de cliënt zijn toegevoegd. }\end{array}$ & $\begin{array}{l}\text { Accountants zouden hun cijferanalyse niet } \\
\text { moeten starten met het kennisnemen van de } \\
\text { ongecontroleerde cijfers en verklaringen van } \\
\text { de cliënt, maar met eigen vooraf ontwikkelde } \\
\text { verwachtingen. Hiermee wordt voorkomen } \\
\text { dat mogelijke fouten in de cijfers tijdens de } \\
\text { cijferanalyse onopgemerkt blijven. }\end{array}$ & $\begin{array}{l}\text { Kinney en Uecker. } 1982 \\
\text { Biggs en Wild, } 1985 \\
\text { Shields, Solomon en Waller, } 1988 \\
\text { Heintz en White, } 1989 \\
\text { Wild en Biggs, } 1990 \\
\text { Heintz. White en Bedard, } 1995 \\
\text { Vaassen en Hassink, } 1995\end{array}$ \\
\hline $\begin{array}{l}3 \text { Cijferanalyses die betrekking hebben op een } \\
\text { meer gedetailleerde periode leiden tot } \\
\text { zinvollere en betrouwbaardere analyse. }\end{array}$ & $\begin{array}{l}\text { Accountants zouden moeten overwegen om } \\
\text { cijferanalyses uit te voeren op basis van } \\
\text { maand- of kwartaalcijfers in plaats van jaar- } \\
\text { cijfers (met name bij omzet- en marge-analyse). }\end{array}$ & $\begin{array}{l}\text { Kinney, } 1987 \\
\text { Knechel, 1988b }\end{array}$ \\
\hline $\begin{array}{l}4 \text { Kwantificering van mogelijke verklaringen } \\
\text { van een onverwachte fluctuatie leidt tot een } \\
\text { betere uitvoering van cijferanalyse. }\end{array}$ & $\begin{array}{l}\text { Het maken van een eenvoudige journaalpost } \\
\text { of berekening van het effect van de verklaring } \\
\text { op de fluctuatie, kan voorkomen dat ten on- } \\
\text { rechte een redelijk lijkende verklaring voor } \\
\text { de fluctuatie wordt geaccepteerd. }\end{array}$ & $\begin{array}{l}\text { Kinney, } 1987 \\
\text { Anderson en Koonce. } 1995\end{array}$ \\
\hline $\begin{array}{l}5 \text { Ervaren accountants zijn beter in staat om } \\
\text { patronen van fouten en de onderliggende } \\
\text { oorzaken te herkennen. Deze patronen } \\
\text { verschillen tussen posten in de jaarrekening, } \\
\text { per onderneming en per branche. }\end{array}$ & $\begin{array}{l}\text { Kennisoverdracht over verschillende soorten } \\
\text { fouten, de onderliggende oorzaken en de ver- } \\
\text { banden in de jaarrekening door ervaren } \\
\text { accountants aan nieuwe assistenten kan } \\
\text { plaatsvinden door middel van op cijferanalyse } \\
\text { gerichte reviews. het ontwikkelen van } \\
\text { handleidingen en interne/externe cursussen. }\end{array}$ & $\begin{array}{l}\text { Libby en Frederick, } 1990 \\
\text { Bonner, } 1990 \\
\text { Bedard en Biggs, 1991a } \\
\text { Bedard en Biggs, 1991b } \\
\text { Bedard, Biggs en Pietro, } 1993\end{array}$ \\
\hline $\begin{array}{l}6 \text { Accountants gebruiken cijferanalyse om } \\
\text { situaties te identificeren die tot een toename } \\
\text { leiden in het standaard werkprogramma. } \\
\text { Ze gebruiken cijferanalyse echter niet vaak } \\
\text { om het standaard werkprogramma in } \\
\text { omvang te reduceren. }\end{array}$ & $\begin{array}{l}\text { Beoordeel de mogelijkheden om het standaard } \\
\text { werkprogramma te reduceren in die posten } \\
\text { in de jaarrekening waarin cijferanalyse geen } \\
\text { onverwachte fluctuaties laat zien. }\end{array}$ & $\begin{array}{l}\text { Biggs, Mock en Watkins, } 1988 \\
\text { Cohen en Kida, } 1989 \\
\text { Bedard. } 1989\end{array}$ \\
\hline
\end{tabular}


viteit van de controle afnemen als de fout ook na uitvoering van de controle niet wordt gesignaleerd. In de praktijk zou het risico op het niet tijdig signaleren van materiële fouten kunnen worden verkleind door voorafgaand aan de uitvoering van cijferanalyse een eigen verwachtingspatroon voor de cijfers te creëren. Het creëren van een verwachtingspatroon is gericht op het beter voorbereid zijn bij de uitvoering van initiële cijferanalyse en kan worden gevormd door voorafgaande aan de controle (opnieuw) de cijfers van vorig jaar en recente ontwikkelingen te bestuderen.

Tevens blijkt dat cijferanalyses die gebaseerd zijn op maandcijfers en onderverdeeld in segmenten meer materiële fouten zichtbaar maken dan gecumuleerde jaarcijfers. Dit is het duidelijkst bij de analyse van omzet en brutomarges. Een voor de jaarrekening materiële fout zal bij een omzet- en marge-analyse op jaarbasis een veel kleinere kans op ontdekking hebben dan bij een analyse op maandbasis. Een nadere onderverdeling naar productgroep of -segment op maandbasis geeft een nog grotere kans op ontdekking.

Accountants blijken verder moeite te hebben om elke hypothese op zijn merites te evalueren. Het blijkt dat de kwaliteit van de cijferanalyse wordt verhoogd als de accountant niet alleen de hypothese globaal test op redelijkheid. maar tevens een kwantificering maakt van het effect van de veronderstelde oorzaak op de geconstateerde fluctuatie. Een dergelijke kwantificering kan bijvoorbeeld bestaan uit een in journalalpostvorm beredeneerd effect. Hiermee wordt het risico verkleind dat een redelijk lijkende - maar onjuiste - verklaring voor de fluctuatie wordt geaccepteerd.

Tot slot blijkt dat accountants cijferanalyse gebruiken als een signaal voor risicovolle posten tijdens de controle, maar niet als mogelijkheid om controlewerkzaamheden te verminderen als er geen onverwachte fluctuaties worden geconstateerd. Een mogelijke efficiency-verhoging van de controle wordt hiermee niet voldoende benut. De mogelijkheden tot het verminderen van overige controlewerkzaamheden doen zich met name voor bij cijferanalyses tijdens de uitvoeringsfase van de controle. Voor controle van de overige bedrijfskosten kan bijvoorbeeld veelal met cijferanalyse worden volstaan. Nadere detailcontrole naast deze cijferanalyse zou alleen nodig zijn indien de cijferanalyse onverwachte fluctuaties aangeeft of om andere specifieke redenen. De mogelijkheden om overige controlewerkzaamheden te verminderen na uitvoering van de initiële cijferanalyse zijn waarschijnlijk kleiner. De initiële cijferanalyse is immers met name bedoeld als 'ondersteuning van het verkrijgen van inzicht in de bedrijfsactiviteiten en het herkennen van potentiële risicogebieden " (NIVRA, 1996, p. 339). Vermindering van controlewerkzaamheden lijkt alleen verdedigbaar als de cijferanalyse een bevestiging weergeeft van een in vorig jaar ingezette vermindering van controlerisico's in bepaalde posten van de jaarrekening.

Voor de volledigheid zij vermeld dat het effect van de onderzoeksbevindingen op de efficiency en effectiviteit van de controle afhankelijk is van omgevingsvariabelen in elke specifieke praktijksituatie (Kreutzfeldt en Wallace, 1986). Zo is bijvoorbeeld het risico van onjuistheden in interne cliëntrapportages lager bij een cliënt met sterke $\mathrm{AO} / \mathrm{IC}$ daun bij een cliënt met een zwakke $\mathrm{AO} / \mathrm{IC}$ (Asare en Davidson, 1995) en zal de gedetailleerdere cijferanalyse een afweging zijn van kosten (tijd) en baten (verwachte meerwaarde voor de controle).

\section{Samenvatting en aanbeveling}

Cijferanalyse is een belangrijk controlemiddel voor het ontdekken van materiële fouten in de jaarrekening. Verbetering van de wijze van uitvoeren van cijferanalyses geeft mogelijkheden tot het verhogen van de efficiency en effectiviteit van de controle als geheel.

Onderzoek naar cijferanalyse richt zich met name op de wijze waarop de oordeelsvorming van de accountant tot stand komt. Deze oordeelsvorming bestaat in grote lijnen uit vijf fasen: bepalen van de doelstelling en onderzoeksrichting, het genereren van hypothesen, zoeken valn informatie, het evalueren van hypothesen en het nemen van beslissingen over de aard, timing en omvang van verdere controlewerkzaamheden.

In dit artikel is besproken dat onderzoeksbevindingen aangeven dat de kwaliteit van uitvoering van cijferanalyse kan worden verhoogd als rekening wordt gehouden met een aantal belangrijke aspecten. Zo is de kwaliteit van cijferanalyses te verhogen door het opbouwen van een eigen verwachtingspatroon voorafgaande aan het 
gebruik van ongecontroleerde interne rapportages en verklaringen van de cliënt, het gebruik maken van meer gedetailleerde perioden, het kwantificeren van mogelijke verk laringen en het gericht overdragen van kennis op minder ervaren leden van het controleteam. Daarnaast biedt cijferanalyse in bepaalde omstandigheden de mogelijkheid om het standaard werkprogramma te reduceren.

Toekomstig onderzoek zal moeten aantonen in hoeverre de samenhang van omgevingsvariabelen in specifieke situaties van invloed kan zijn op de ontdekkingskansen van fouten in de jaalrekening tijdens de uitvoering van cijleranalyse.

\section{I T ER A T U U R}

Anderson, J.C., S. Kaplan en P. Reckers, (1992), The effects of output interference on analytical procedures judgments, Auditing: a Journal of Practice and Theory (Fall), pp. 1-13.

Anderson, U. en L. Koonce, (1995), Explanations as a Method for Evaluating Client-suggested Causes in Analytical Procedures, Auditing: a Journal of Practice and Theory (Fall), pp. 125-132.

Asare, S.K. en R.A. Davidson, (1995), Expectation of Errors in Unaudited Book Values: The effect of Control Procedures and Financial Condition, Auditing: a Journal of Practice and Theory, pp. 1-18

Bedard, J.C., (1989), An Archival Investigation of Audit Program Planning, Auditing: a Journal of Practice and Theory, pp. 57-71.

Bedard, J.C. en S.F. Biggs, (1991a), Pattern Recognition, Hypotheses Generation and Auditor Performance in an Analytical Task, The Accounting Review, pp. 622-642.

Bedard, J.C. en S.F. Biggs, (1991b), The Effect of DomainSpecific Experience on Evaluation of Management Representations in Analytical Procedures, Auditing: a Journal of Practice and Theory, pp. 77-90.

Bedard, J.C, S.F. Biggs en J. DiPietro, (1993), The impact of auditor analytical procedures hypotheses and management representations on audit planning decisions, unpublished working paper

Biggs, S.F., T.J. Mock en P.R. Watkins, (1988), Auditors' use of Analytical Review in Audit Program Design. The Accounting Review, pp. 148-161

Biggs, S.F., T.J. Mock en P.R. Watkins, (1989), Analytical Review Procedures and processes in Auditing, The Canadian Certified General Accountants Foundation: Vancouver, Canada.
Biggs, S.F., T.J. Mock en P.R. Watkins, P.R., (1995), Auditor Judgment Research in Analytical Procedures: Implications for Practice, MARC Working Paper.

Blokdijk, J.H., (1996), Toedeling van controletolerantie bij de accountantscontrole, Maandblad voor Accountancy en Bedriffseconomie, juli/augustus, pp. 350-360.

Blokdijk, J.H., F. Drieënhuizen en P. Wallage, (1995), Reflections on Auditing Theory: A contribution from the Netherlands, Kluwer Bedrijfswetenschappen, Deventer/Limperg Instituut, Amsterdam.

Bonner, S., (1990), Experience Effects in Auditing: The role of task-specific Knowledge, The Accounting Review, (January) pp. 72-92.

Cohen, J. en T. Kida, (1989), The Impact of Analytical Review Results, Internal Control Reliability and Experience on Auditors' Use of Analytical Review, Journal of Accounting Research, pp. 263-276.

Heiman, V.B., (1990), Auditors' Assessments of the Likelihood of Error Explanations in Analytical Review. The Accounting Review, pp. 875-890.

Heintz, J.A. en G.B. White, (1989), Auditor Judgment in Analytical Review: Some Further Evidence, Auditing: a Journal of Practice and Theory, pp. 22-39.

Houghton, C.W. en J.A. Fogarty, (1991), Inherent Risk, Auditing: A Journal of Practice and Theory, Vol. 10, No. 1 , pp. 1-21

Kinney, W.R., (1987), Attention directing analytical review using accounting ratios: A case study, Auditing: a Journal of Practice and Theory (Spring), pp. 59-73.

Kinney, W.R. en W.C. Uecker, (1982), Mitigating the Consequences of Anchoring in Auditor Judgments, The Accounting Review, pp 55-69

Knechel, W.R., (1988), The effectiveness of nonstatistical analytical Review Procedures used as Substantive audit tests, Auditing: a Journal of Practice and Theory (Fall), pp. 87-107

Koonce, L., (1992), Explanation and counterexplanation during audit analytical review, The Accounting Review, (January): pp. 59-76.

Koonce, L., (1993), A Cognitive Characterization of Audit Analytical Review: some further evidence, Auditing: a Journal of Practice and Theory, (supplement) pp. 57-69.

Kreutzfeldt, R.W. en W.A. Wallace, (1986), Error Characteristics in Audit Populations: Their Profile and Relationship to Environmental Factors, Auditing: a Journal of Practice and Theory (Fall), pp. 21-43.

Libby, R., (1985), Availability and the Generation of Hypotheses in Analytical Review, Journal of Accounting Research, pp. 649-667.

Libby, R. en D. Frederick, (1990), Experience and the ability to explain audit findings, Journal of Accounting Research, (Autumn) pp. 348-367 
NIVRA, (1996), Richtliin Accountantscontrole 520 Cijferanalyse.

Shields, M., I. Solomon en W. Waller, (1988), Auditors' Usage of Unaudited Book Values When Making Presampling Audit Value Estimates, Contemporary Audit Research, (Fall) pp. 1-18

Vaassen, E.H.J. en H.F. D. Hassink, (1995), Oordeelsvorming bij Initiële Cijferanalyse in de Accountantscontrole, Maandblad voor Accountancy en Bedriffeconomie, november pp. 652-663.

Wallage, P., (1993), Internationalising Audit: A study of audit approaches in the Netherlands, The European Accounting Review, Vol. 3, pp. 555-578.

Wright, A. en R. Ashton, (1989), Identifying audit adjustments with attention directing procedures, The Accounting Review (October), pp. 710-728.
Wild, J.J. en S.F. Biggs, (1990), Strategic Considerations for unaudited Account Values in Analytical Review, The Accounting Review (January), pp. 227-241

Wolde, J ten, (1989), Moderne controle-aanpak, KPMG AUDIT: het controleproces bij KPMC KKC, Maandblad voor Accountancy en Bedriffeconomie, oktober.

Wolde, J. ten, (1990), Nederlandse versus Amerikaanse accountantscontrole, Maandblad voor Accountancy en Bedriffseconomie, maart, pp. 78-85

\section{N 0 O T}

1 De auteurs bedanken Jan-Paul Leerentveld, Eddy Vaassen, Arnold Schilder en Steven Maijoor voor hun commentaar op eerdere versies van dit artikel. 